\title{
LPS-induced gene expression of inflammation- related genes in neutrophils from familial Mediterranean fever patients
}

\author{
Gayane Manukyan ${ }^{1,2^{*}}$, Eva Kriegova ${ }^{2}$, Anush Martirosyan $^{1}$, Regina Fillerova ${ }^{2}$, Maretta Tatyan ${ }^{1}$, Martin Petrek ${ }^{2}$ \\ From 7th European Workshop on Immune-Mediated Inflammatory Diseases \\ Noordwijk aan Zee, the Netherlands. 28-30 November 2012
}

\section{Background}

Autoinflammatory disorders, such as Familial Mediterranean fever (FMF), characterized by abnormally increased inflammation, and mediated predominantly by the cells of innate immune system. FMF characterized by the episodes of self-resolving severe inflammation, with fever and serositis. The major cell type found in FMF inflammatory exudates are neutrophils. It is not known whether bacterial lipopolysaccharide (LPS) could influence neutrophil activation in FMF. We examined in vitro effect of LPS $(10 \mathrm{ng} / \mathrm{ml})$ exposure on expression of 13 selected genes in FMF and control neutrophils using quantitative real-time RT-PCR.

\section{Results}

LPS exposure induced basal expression of TLR4 (4.4-fold increase, $\mathrm{p}<0.05$ ), IL-1 $\beta$ (9-fold, $\mathrm{p}<0.01$ ), IL-8 (13-fold, $\mathrm{p}=0.06)$, TNFAIP6 (11-fold, $\mathrm{p}<0.05)$ genes in FMF neutrophils, and of TLR4 (17.6-fold, $\mathrm{p}<0.001)$, IL-1 $\beta$ (25fold, $\mathrm{p}<0.001)$, IL-8 (36-fold, $\mathrm{p}<0.001)$, TNFAIP6 (61fold, $\mathrm{p}<0.001$ ) in healthy neutrophils.

\section{Conclusions}

Our findings indicate that gene expression in LPS-exposed FMF and control neutrophils is characterized by a number of shared alterations. In spite of pre-activated state of FMF neutrophils, LPS exposure further enhanced expression of the investigated genes. The ability of FMF neutrophils to enhance LPS-induced inflammatory reaction was however attenuated compared to healthy neutrophils. In conclusion, our data indicate that FMF neutrophils may display

'Group of Molecular and Cellular Immunology, Institute of Molecular Biology, National Academy of Sciences, Yerevan, Armenia

Full list of author information is available at the end of the article features of LPS tolerance, and this speculation should be explored further.

\section{Acknowledgements}

Grant support: IGA_PU_LF_2012_007 and ANSEF NS_1987

\section{Author details}

'Group of Molecular and Cellular Immunology, Institute of Molecular Biology, National Academy of Sciences, Yerevan, Armenia. ${ }^{2}$ Laboratory of Immunogenomics and Proteomics, Medical Faculty, Palacky University, Olomouc, Czech Republic.

Published: 28 November 2012

doi:10.1186/1479-5876-10-S3-P56

Cite this article as: Manukyan et al: LPS-induced gene expression of inflammation-related genes in neutrophils from familial Mediterranean fever patients. Journal of Translational Medicine 2012 10(Suppl 3):P56. and take full advantage of:

- Convenient online submission

- Thorough peer review

- No space constraints or color figure charges

- Immediate publication on acceptance

- Inclusion in PubMed, CAS, Scopus and Google Scholar

- Research which is freely available for redistribution 